\title{
Retrieving Trends and Issues of Penyiaran/Broadcasting in Malaysian Parliamentary Debates from 1957 To 2018: A Culturomics Approach
}

\author{
JAMALUDDIN AZIZ \\ Universiti Kebangsaan Malaysia
}

\begin{abstract}
The traditional concept of broadcasting is gradually becoming a misnomer due to technological transformations as epitomized by media convergence. Past studies on broadcasting in Malaysia often employed historical perspectives, policy analysis and technology impact frameworks. Thus far, no study has been carried out tracing Malaysian broadcasting issues over six decades. The knowledge of how penyiaran/broadcasting is debated in Parliament over time provides insights into the changing concerns in broadcasting throughout history in Malaysian context from the perspectives of the policy makers. The objectives of this research are to identify: 1) The frequency of the words penyiaran and broadcasting in Malaysian Hansard; 2) Patterns related to penyiaran/broadcasting in Malaysian Hansard; 2) Some issues as reflected by the patterns generated by the $n$-gram. This research employs both quantitative and qualitative approaches to analyze Malaysian Hansard Corpus (MHC) with about 157 million words from Parliament 1 (1959) to Parliament 13 (2018). Using AntConc software, culturomics is the quantitative approach that provides a tool to turn cultural patterns into empirical data. The pattern is generated in the form of an n-gram. The collocations retrieved help to identify the contexts of the issues and provide data for qualitative textual analysis. The main finding of this research is that the words penyiaran/broadcasting have lost its utility due to media convergence. The impact of the study is that it evokes ontological enquiry useful for media scholars, lawmakers and media practitioners to understand the changing conception of broadcasting so that more adaptive approaches and policies can be legislated.
\end{abstract}

Keywords: Culturomics, broadcasting, Malaysian Hansard Corpus, policies, Malaysian parliamentary debate.

\section{INTRODUCTION}

The motivation of this paper finds its origin in the two "media" events that took place in Malaysia recently. First, it is when the Chief Executive Officer (CEO) of FINAS (National Film Development Corporation Malaysia) raised an issue related to the regulation of the media content on digital platform, evoking the need to censure a streaming channel - Netflix - so as to be "fair" to locally produced programs that are subjected to censorship (Norhafiza Musa, 2019). Two, the recent International Conference on Media and Communication 2019 organized by the Centre for Research in Media and Communication, Faculty of Social Sciences and Humanities, Universiti Kebangsaan Malaysia, with the main theme: Transformation and Convergence in the Media and Communication. To my mind, these two events evoked a fundamental question regarding the shift in the ontological status of broadcasting as we know it: What is broadcasting now? Consequently, this creates what I would call an epistemological uncertainty as encapsulated in the question: "How do we understand broadcasting in the era of convergence?" Indeed, while the first alludes to the fluidity of concept, the latter hints at 
methodological innovations. This paper is related to that idea in the sense that it retrieves the movement of the word penyiaran and broadcasting from 1959 to 2018 as indicated in Malaysian Hansard, to expose the patterns and issues of broadcasting during that period.

Historically, broadcasting in Malaysia played a special role towards the nation's progress. In the West, radio broadcast as mass communication started in the early 1920s and immediately gained popularity, as it was "the first mass medium that brought sports, music, talk, and news into the living room" (Dominick, 2011, p.62). In Malaysia, broadcasting started with radio broadcasting that began, according to Asiah Sarji, before the official launch of British-Malaya Broadcasting Corporation (BMBC) in 1937 (1982, p.151). Radio broadcasting service in (British) Malaya (the old name for Malaysia) under BMBC was affected and ceased operation due to the Second World War in 1938. And then, during the Japanese occupation for $3 \frac{1}{2}$ years in Malaya in 1945, a few new radio stations were built; however, it was considered the reason for "Radio Malaya's brief decline" (1982, p.152). When the British returned to Malaya, the administration of broadcasting in Malaysia was supervised by Broadcasting Department of Malaya (Asiah Sarji, 1982). Broadcasting then was not commercially run as it played an important role in rehabilitating a postwar society and in preparing the nation towards its Independence. Meanwhile, the same roles are also played by TV broadcasting in Malaysia that was first introduced on 28th December 1963 (Meor Zailan Sulaiman, 1992, p.105) until the introduction of the first private television station, known as TV3, on $1^{\text {st }}$ of June, 1984 (Meor Zailan, 1992, p.107)

Since over three decades ago, broadcasting has been seen as pervasive as it is overtly affected by the development and innovations in the media and communication technology globally. Scholars have since been contemplating the effects that technology has on broadcasting in the aspects of policies and ownerships, market economy, technocratic practices, media education, culture and even the environment. One such study is the one done by Leonard Hugh whose work sums up this transformation in Asia by proposing two important drivers: "technology and deregulation", which can be seen mainly in the employment of "satellite technology [...] and a relaxation [of government's grip]", respectively (1993, p.124). Likewise, Daeho Kim succinctly talks about the tension of the convergence that broadcasting and telecommunication experience, as there is a need for "regulatory framework to change, as new services are created and markets converge" (2011, p.155). The idea here is that there is an urgent need for reform as the current regulation is not flexible enough to capture the changes in broadcasting and its convergence.

Several studies that have been done that looked at the development of broadcasting in Malaysia employed historical perspectives, policy analysis and technology impact frameworks. These previous studies are considered thematically isolated and divisive; thus, unable to provide a more bird-eye view of broadcasting issues as discussed by Malaysian lawmakers. This has resulted is an inchoate delineation of the issues. This study identifies the inchoate delineation as the gap and problem of this study. For the purpose of this study, two keywords are used, the Malay word penyiaran and its English counterpart, broadcasting. This is simply because both languages are used in Malaysian Parliament. To use only the Malay word, for instance, will only distort the data collected as the emphasis is on investigating the issues related to broadcasting from the lawmakers' perspective. 
Thus far, no study has been carried out that specifically looks at Malaysian broadcasting issues as discussed in Malaysian Parliament by using culturomics approach. This paper presents the research using Malaysian Hansard Corpus (henceforth, MHC). The objectives of this research are:

1) To identify the frequency of the words penyiaran/broadcasting in Malaysian Hansard;

2) To identify some patterns related to issues in penyiaran/broadcasting in Malaysian Hansard;

3) To identifies some issues related to penyiaran and broadcasting as reflected by the patterns generated by the n-gram.

\section{BRIEF INTRODUCTION TO PARLIAMENTARY DEBATES AND MALAYSIAN HANSARD CORPUS}

Parliamentary debates are central in keeping democracy alive. According to Jamaluddin Aziz, "the interest in studying parliamentary discourse is increasing as parliament is a place where national and international issues are debated; subsequently, policies and laws are passed; thus, marking the vibrancy of democracy" (2019, p.280). This is perhaps due to the idea that according to Treimane (2011, p.79), parliamentary discourse can be understood by three features:

1. It is the most formal and institutionalized variety of political discourse;

2. It displays fixed, recurrent communication patterns which both shape and restrict the mode of communication;

3. It requires a contextual approach of analysis.

Parliamentary discourse as in MHC is therefore useful in understanding how penyiaran and broadcasting is discussed and institutionalized over the years.

Malaysian Hansard Corpus was developed by the Digital Humanities research team from the Faculty of Social Sciences and Humanities, UKM. This is a group that employs the big data to study the issues in social sciences and humanities by using technology as a tool. Digital humanities are often seen as a field that foregrounds "the use of algorithms to search meaning in databases of text and other media" (Hand, 2011, p.439), which allows meaning to be assigned to computed data. The present paper attempts to assign meaning to the database of $\mathrm{MHC}$.

The corpus consists of over 157 million words, from Parliament 1 (P1) and Parliament 13 (P13), that is, from the year 1959 to 2018. The details of this corpus are presented in the methodology section.

\section{LITERATURE REVIEW}

Broadcasting has been studied in many aspects and approaches. Previous studies have not only proven that broadcasting is central in mass communication but also establishes its relationship with politics, economy and culture. This literature review covers some themes of past studies related to broadcasting locally and internationally. 
The first theme identified is the role of broadcasting, which appears mostly in the earlier studies of broadcasting. These studies usually make a link between broadcasting and nationbuilding; thus, reflecting the role of broadcasting within the discourse of development. Asiah Sarji (1982), for instance, studies the functions of radio broadcasting during the preIndependence Malaysia. She reveals that the historical link that radio broadcasting has with its British progenitor qualifies the practice of broadcasting as "guided broadcasting" in which the persuasive message of allegiance and solidarity with the government of the day is central (1982, p.158). Similarly, Meor Zailan Sulaiman (1992) whose work hinges on retrospective approach observes that before the 80s, commercial TV broadcasting in Malaysia did not exist although advertisings were carried by both public television and radio. Indeed, he claims that this is due to the legacy of the British that sees the role of broadcasting as "an instrument of public persuasion" (1992, p.103) as its main roles are to inform, educate and entertain the people while maintaining racial harmony. Likewise, Umi Khattab asks the question: "to what extent is the public interest represented through television's central nation-building role in Asian countries such as Malaysia?" (2006, p.347). This idea resonates well with Shazlin Amir Hamzah's study that "discusses the role of the popular patriotic song Tanah Pusaka (1964), in the process of branding the nation through the radio. It focuses on the importance of branding disseminated through the repetition of symbols in songs via the radio" (2019, p.90). Her study finds that the repetition of the song via broadcasting (Radio Malaya), helps to spread "the idea of a collective and shared national identity" (Shazlin Amir Hamzah, 2019, p.100), harking back to the role of broadcasting in not only nation building but also nation branding. It can be concluded that previous studies on broadcasting often link it to its role in nation building.

The second theme often becomes the subject of interest in previous studies on broadcasting is the twinned category of policies and regulation. Leonard Hugh for instance, in discussing the changing scene of broadcasting in Asian countries, points out that "uncontrolled diet of Western television will have a damaging effect on the culture of their country" (1993, p.124). Hugh's argument for regulation centers on the notion of cultural imperialism that is transmitted via media content by the superpowers like America and the United Kingdom. Flew, in discussing policies and regulations in the creative industries, contends that "more extensive regulation of broadcast media has also been reflective of public good elements of the media commodity" (2012, p.161). This essentially means that the lack of proper formula relating the cost of production of a program to the impact on the audience, or the "one to many" model of communication, has resulted in the need to regulate broadcasting even more extensively.

The third theme is related to the social and political implications of broadcasting and technology. In the context of cultural imperialism, John Sinclair concludes that:

The business of international broadcasting is driven by commercial considerations, not any desire for ideological domination as such, and that the revival of the rhetorical critique of cultural imperialism has more to do with attempts by national governments to legitimize their positions in the era of global broadcasting, rather than with any actual cultural influence (1997, p.152). 
The relationship between technology and social practice, as Juliana Abdul Wahab discovers, sees technology by no means neutral as it indeed creates "consumer vulnerability" as a result of the TV station's ability to decide what is best for the consumers (2006, p.14). Juliana comes to this conclusion by studying the development of technology and the ownership of television stations in Malaysia. In the same vein, Dominick argues that while "radio changed the way Americans spent their free time" (2011, p.63), "television also has transformed politics" as it brought political happenings such as the Vietnam war into the American's living room. Meanwhile, Tangguh Okta Wibowo studies "the negotiation of the presence of streaming websites in the context of technoculture, which is the analysis of the interaction between technology, culture, regulation, and the future of cyber world in watching movies" (2019, p.248). As no mention is made of the word broadcasting in his analysis, indicating that the word broadcasting has been lost within the context of convergence; however, he still refers to it in the literature review. The finding of his study is that such convergence has become a site of conflict between "the government, copyright holders, the movie industry and the Movie Producers Association of Indonesia (Asprofi)" (Tangguh Okta Wibowo, 2019, p.257).

It can be concluded here that most previous studies on broadcasting have focused on three main themes, which are the role or function of broadcasting, policies and regulations, and finally the social and political implication of broadcasting and technology.

\section{METHODOLOGY}

The present research employs both quantitative and qualitative approaches. As a quantitative method, culturomics is an approach that enables cultural patterns to be coded as empirical data. Michel et al. argue that culturomics enables the investigation into cultural trends quantitatively; this can be done by examining "both linguistic changes, such as changes in the lexicon and grammar; and cultural phenomena, such as how we remember people and events" (2011, p.3). In other words, culturomics, according to Tahmasebi et al., "is to study human behaviors and cultural trends by analyzing massive amounts of textual data that nowadays are available in digital format" $(2015$, p.169). In this present study, culturomics is used as it helps to illuminate changes in cultural phenomenon such as in the change of the conceptualization of the words penyiaran and broadcasting.

Using AntConc software, the frequencies of each keyword are recorded. The frequencies are generated to show the tendency the words are used in Malaysian Parliament from September 1959 (Parliament 1 (P1)) to April 2018 (Parliament 13 (P13)) with 157 million words as the data of the corpus. From the frequencies, an n-gram is then generated that provides a visual representation of the cultural trend related to both penyiaran and broadcasting.

For the qualitative approach, textual analysis of the concordances is carried out on the MHC. These Hansard texts are selected based on the patterns of occurrence produced in the $\mathrm{n}$ grams, which consist of the first issues discussed on penyiaran and broadcasting, the lowest frequencies of both keywords, the highest frequencies, and the descending and ascending trends. Textual analysis is central in a culturomics approach this research has adopted as it provides a critical appraisal of the quantitative data. Michel et al. succinctly says that "the challenge of culturomics lies in the interpretation of this evidence" $(2011$, p.7). For that reason, 
concordances help retrieve the context in which the issues appeared. Consequently, this allows me to relate the collocates with larger socio-political contexts.

The procedures of data mining follow the 4 step procedures proposed by Norsimah, Azhar, Anis Nadiah and Imran (2019) (in Figure 1) in order to reach the research objectives:

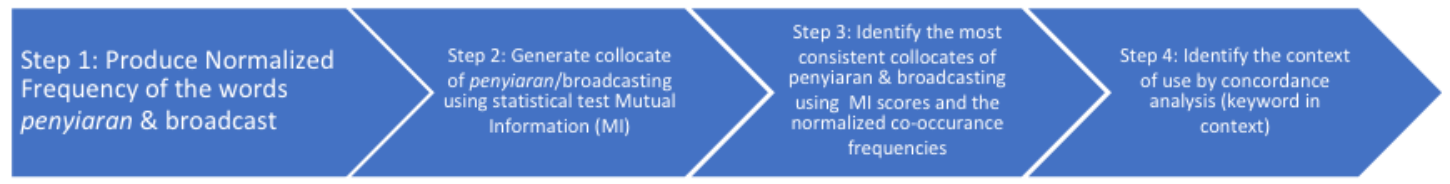

Figure 1: 4 step procedures of data mining

Step 1: This step is to generate the frequency of the keywords penyiaran and broadcasting in each parliamentary sitting. This involves P1 through to P13 as set at mutual information (MI) score of 6 . Using AntConc software, the raw frequency for penyiaran and broadcasting in each parliament was determined. Next, the normalization process of the frequency is carried out. Evinson (in Norsimah et al., 2019, p.105) avers that "[n]ormalization is a process to standardise word count which is done to accurately compare corpora (or sub-corpora) of different sizes." The normalized frequencies are then plotted in an n-gram to identify the trend of occurrence for the word penyiaran and broadcasting from P1 to P13.

Step 2: The next step is to generate the collocates of penyiaran and broadcasting in each parliament sitting. Collocation is "a co-occurrence relationship between words or phrases. Words are said to collocate with one another if one is more likely to occur in the presence of the other than elsewhere" (McEnery, 2013, in Norsimah et al., 2019, p.105). This study sets the minimum MI Score to 6 , and item must have a minimum co-occurrence frequency of 10 , within a 5 (left) - 5 (right) window span to figure out the collocate of keywords given. A higher MI score indicates significant relationship between words. For instance, MI score of 6 is higher than $\mathrm{Ml}$ score of 3, reflecting "a stronger association and thus a more coherent relationship between words" (Salazar, 2014, in Norsimah et al., 2019, p.105). As the steps are a duplicate of Norsimah et al. (2019) method, the study adopts the idea that the MI score is suitable with content words rather than function words. Using this setting, greater statistically significant differences of the collocations can be produced.

Step 3: This step strengthens the analysis by identifying the most consistent collocate/s of penyiaran and broadcasting. The $\mathrm{MI}$ scores and the normalized co-occurrent frequencies of the identified collocate/s were recorded manually and then plotted and presented in a n-gram graph.

Step 4: After identifying the trends, certain issues are addressed based on the collocate/s and concordance/s of penyiaran and broadcasting using textual analysis. 


\section{RESULTS AND ANALYSIS}

The research finding will be presented in three parts:

Part 1: The frequency of penyiaran and broadcasting in the Malaysian Hansard Corpus (MHC). Part 2: The collocates of penyiaran and broadcasting in each parliamentary session in MHC.

Part 3: The textual analysis of related concordances to establish the context of discussion.

\section{PART 1: FREQUENCY}

This section provides the data to reach the first research objective, that is, to identify the frequency of both words penyiaran and broadcasting. Frequency refers to the number of tendencies that the keyword occurs in the parliamentary debates. To understand a bigger picture of the parliament's tendency to discuss issues related to penyiaran/broadcasting, frequency is useful in showing the pattern of occurrence that can be used to generate the $n$ gram. For a guideline, the size (word of running number) of sub-corpora (Imran et al., 2017) is presented in Table 1.

Table 1: The size (token of running number) of sub-corpora in MHC.

\begin{tabular}{ll}
\hline Parliament & No of Sub-corpora \\
\hline 1 & 6060551 \\
2 & 9893721 \\
3 & 6264859 \\
4 & 8040934 \\
5 & 8691728 \\
6 & 9485250 \\
7 & 9106187 \\
8 & 15171864 \\
9 & 12919341 \\
10 & 14123916 \\
11 & 17047556 \\
12 & 22188820 \\
13 & 18517944 \\
\hline
\end{tabular}

Table one shows the total number of words (157 millions) in MHC.

Table 2: shows the normalized frequency of the words penyiaran and broadcasting from P1 to P13

\begin{tabular}{cccc}
\hline Parliament & Penyiaran & Broadcasting & Year \\
\hline P1 & 286 & 223 & $1959-1964$ \\
P2 & 105 & 120 & $1964-1969$ \\
P3 & 151 & 95 & $1971-1973$ \\
P4 & 178 & 97 & $1974-1978$ \\
P5 & 37 & 16 & $1978-1981$ \\
P6 & 212 & 54 & $1982-1986$ \\
P7 & 171 & 61 & $1986-1990$ \\
P8 & 238 & 94 & $1990-1994$ \\
P9 & 497 & 89 & $1995-1999$ \\
P10 & 953 & 113 & $1999-2003$ \\
\hline
\end{tabular}


Retrieving Trends and Issues of Penyiaran/Broadcasting in Malaysian Parliamentary Debates from 1957 To $2018:$ A Culturomics Approach

Jamaluddin Aziz

\begin{tabular}{llcl}
\hline P11 & 643 & 110 & $2004-2007$ \\
P12 & 694 & 67 & $2008-2012$ \\
P13 & 376 & 35 & $2013-2018$ \\
\hline
\end{tabular}

Table 2 shows the normalized frequency of the words penyiaran and broadcasting from P1 to P13. The highest frequency recorded for penyiaran is in P10, while for broadcasting, the highest frequency recorded is in P1. This may be due to the fact that the English language was still widely used in Parliament immediately after the Independence. The table also shows that the lowest frequency for penyiaran and broadcasting is in P5. Both words seem to be gaining momentum in P10 (the peak for penyiaran) in 1999. These frequencies are plotted in the $\mathrm{n}$ grams in Figure 2 and 3 below to show the pattern of occurrences for both penyiaran and broadcasting.

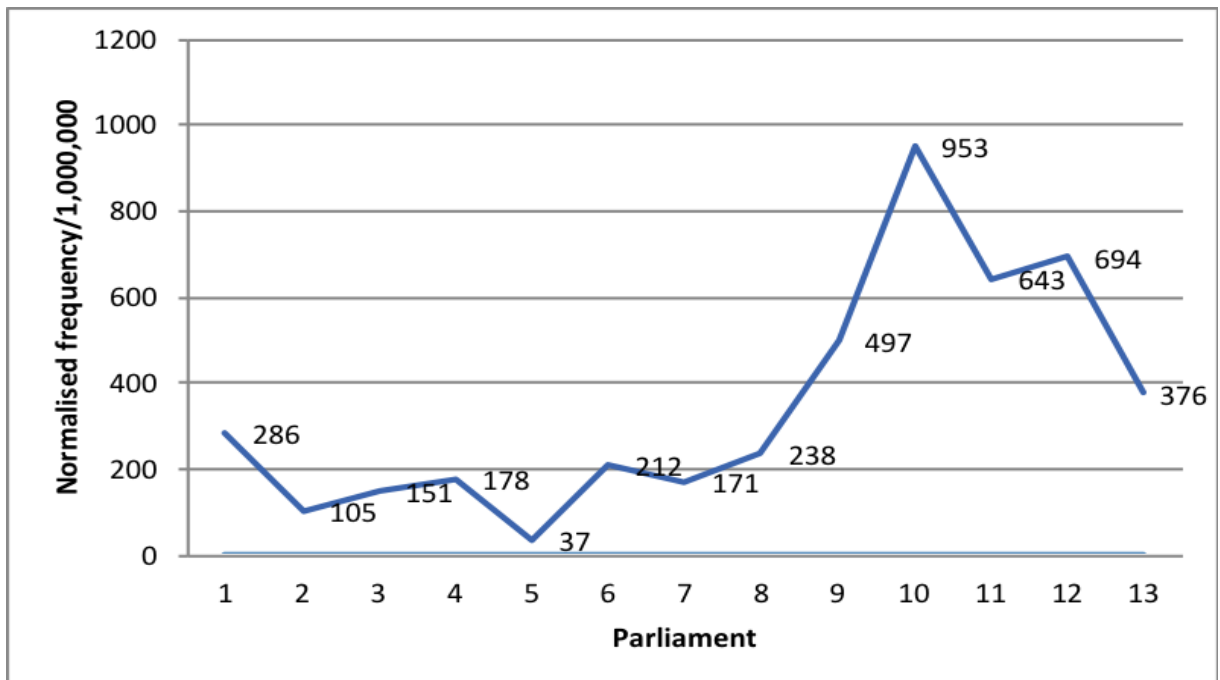

Figure 2: n-gram of normalized frequencies of penyiaran

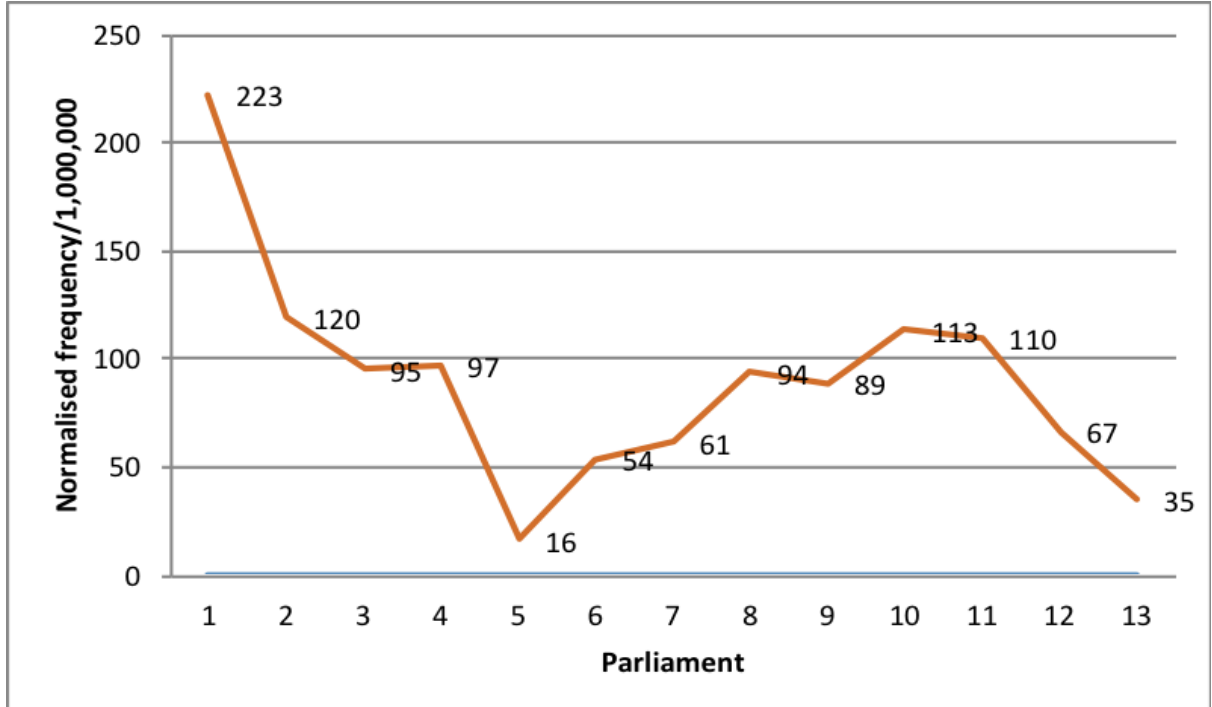

Figure 3: n-gram of normalized frequencies of broadcasting 
Figure 2 and 3 show that pattern of occurrences of the keywords penyiaran and broadcasting. Generally, the n-grams show that while the usage of the word penyiaran increases over time, the word broadcasting has lost its utility in Parliament. While Penyiaran reaches its peak in P10 and broadcasting reaches its peak in P1. However, both words reached its nadir in P5. Towards P13, both words also show a decrease in frequency of usage.

\section{PART 2: THE PATTERN OF TRANSFORMATION}

This section presents the finding to address the second objective of the research, which is, to identify the trend of the usage of these two words penyiaran and broadcasting. This can be achieved by identifying the collocates (words that occur with the keywords) and their frequencies. Parallel to Hajar Abdul Rahim's assertion, "the number of the frequency of the collocations can inform about the behavior of the collocations studied" (2005, p.96).

Table 3: Normalized Frequency of the Most Consistent Collocate (Broadcasting)

\begin{tabular}{cccccc}
\hline Parliament & Freq & $\begin{array}{c}\text { MI } \\
\text { Scores }\end{array}$ & Collocate & Total of collocate token & $\begin{array}{c}\text { Freq/per 10000 } \\
\text { (normalized) }\end{array}$ \\
\hline$P 1$ & 256 & 11.46185 & information & 4070 & 256 \\
$P 2$ & 429 & 12.1451 & information & 5050 & 429 \\
$P 3$ & 14 & 12.49815 & information & 330 & 14 \\
$P 4$ & 0 & 0 & 0 & 0 & 0 \\
$P 5$ & 0 & 0 & 0 & 0 \\
$P 6$ & 0 & 0 & 0 & 0 \\
$P 7$ & 0 & 0 & 0 & 0 \\
$P 8$ & 0 & 0 & 0 & 0 \\
$P 9$ & 0 & 0 & 0 & 0 \\
$P 10$ & 0 & 0 & 0 & 0 \\
$P 11$ & 0 & 0 & 0 & 0 \\
$P 12$ & 0 & 0 & 0 & 0 & 0 \\
$P 13$ & 0 & 0 & 0 & 0 \\
\hline
\end{tabular}

Table 3 shows the normalized frequency of the most consistent collocate of broadcasting. This table shows that the significant collocate is the word information. Nonetheless, the consistency only occurs in P1 to P3. This pattern of transformation is indicated by the two words (broadcasting and information) that seem to have lost their linkage after that. This is further shown in Figure 4. 
Retrieving Trends and Issues of Penyiaran/Broadcasting in Malaysian Parliamentary Debates from 1957 To $2018:$ A Culturomics Approach

Jamaluddin Aziz

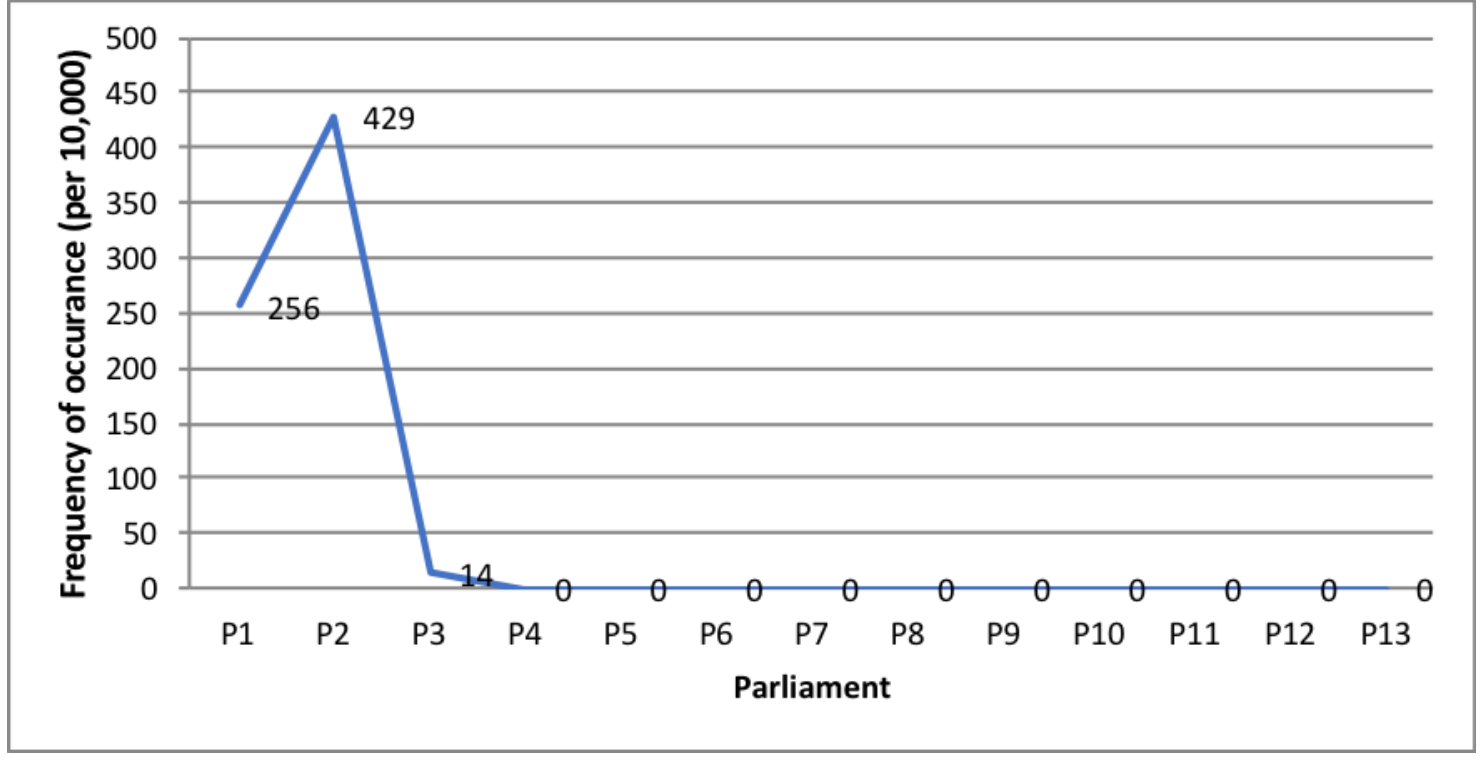

Figure 4: n-gram of normalized frequencies of collocate (broadcasting)

Figure 4 shows the $n$-gram of normalized frequency of collocates of broadcasting.

Table 4: Normalized Frequency of the Most Consistent Collocate (Penyiaran)

\begin{tabular}{ccclcc}
\hline PARLIAMENT & FREQ & MI SCORES & COLLOCATE & $\begin{array}{c}\text { TOTAL OF COLLOCATE } \\
\text { TOKEN }\end{array}$ & $\begin{array}{c}\text { FREQ/PER } \\
\text { 10000 } \\
\text { (NORMALIZED) }\end{array}$ \\
\hline P1 & & & & & 0 \\
P2 & 366 & 11.86057 & penerangan & 190 & 366 \\
P3 & 19 & 8.98246 & penerangan & 5020 & 19 \\
P4 & 20 & 9.46264 & penerangan & 570 & 20 \\
P5 & 29 & 9.01198 & penerangan & 1530 & 29 \\
P6 & 21 & 8.87613 & penerangan & 1360 & 21 \\
P7 & 20 & 7.62206 & penerangan & 3050 & 20 \\
P8 & 26 & 8.41616 & penerangan & 3030 & 26 \\
P9 & 53 & 8.2613 & penerangan & 6730 & 53 \\
P10 & 14 & 8.25605 & penerangan & 2640 & 14 \\
P11 & 40 & 8.61998 & penerangan & 5000 & 40 \\
P12 & 22 & 9.00008 & penerangan & 2920 & 22 \\
P13 & 10 & 9.64807 & penerangan & 1750 & 10 \\
\hline
\end{tabular}

Table 4 shows the normalized frequency of the most consistent collocate for penyiaran that is penerangan or information. This pattern of transformation is indicated by the the word penerangan that is the consistent pair of the word penyiaran throughout $\mathrm{P} 2$ to $\mathrm{P} 13$. This is also shown in Figure 5. 


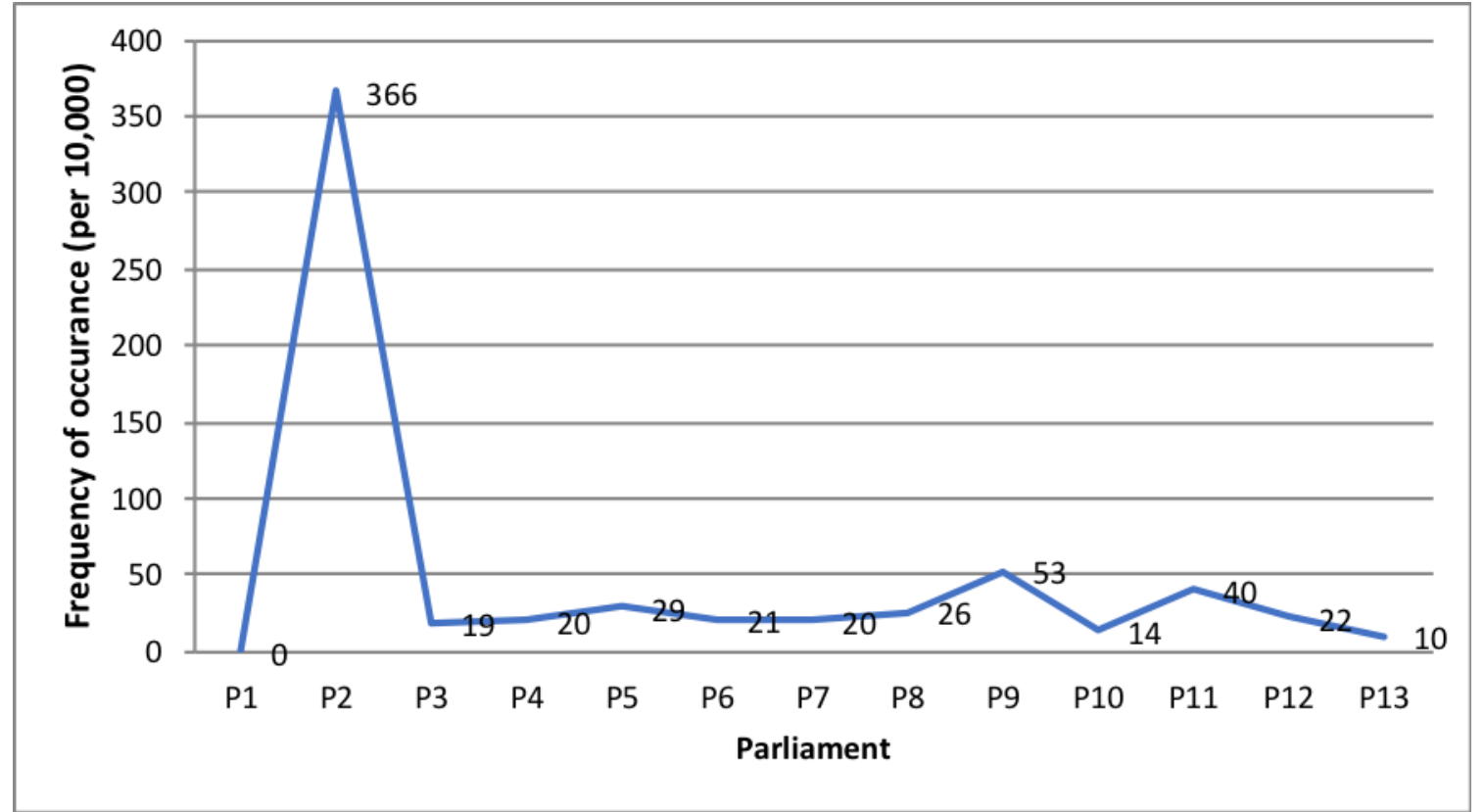

Figure 5: n-gram of normalized frequencies of collocate (penyiaran)

PART 3: ISSUES RELATED TO PENYIARAN AND BROADCASTING

Part 3 provides the qualitative approach to $\mathrm{MHC}$ by analyzing the relevant discourse as plotted in the n-grams. The analysis is carried out on the concordance (retrieved parliament texts). This section is divided into two: 1 ) the analysis based on the keyword penyiaran and 2) the analysis based on the keyword broadcasting. As discussed in the Part 2, both penyiaran and broadcasting have different trends of occurrences.

It is found that Penyiaran:

a) Penyiaran has reached the peak in P10

b) Penyiaran has the lowest frequency in P5

c) The highest collocation with penerangan in P2

d) The lowest collocation with penerangan in P13

e) The first collocation of penyiaran with penerangan (consistent collocation) begins in $\mathrm{P} 2$ not $\mathrm{P} 1$.

f) Penyiaran has consistent collocate with Penerangan from P2 until P13

g) Apart from P2, all other parliaments, beginning from P3 states low frequency of penerangan and keeps declining until P13; although there is a small increase in frequency in P5, P9 and P11.

Based on the above finding, concordance is generated and textual analysis is carried out. Based on the patterns shown in the n-gram, the focus is on penyiaran in P2, P5, P10, and $\mathrm{P} 13$. The next section is divided based on the issues retrieved. 
Retrieving Trends and Issues of Penyiaran/Broadcasting in Malaysian Parliamentary Debates from 1957 To 2018 : A Culturomics Approach

Jamaluddin Aziz

\subsection{P2 Penyiaran in Native Language and Quality Program}

\section{Concordance:}

yokong peruntokan yang di-minta untok Kementerian Penerangan dan Penyiaran ini. Dan saya rasa pada keselurohan-

lam memba-hathkan Anggaran Belanjawan Kementerian Penerangan dan Penyiaran ini. Yang Pertama, Tuan Pengerusi, pada hun yang lalu, ada bayangan2 daripada Kementerian Penerangan dan Penyiaran ini supaya dapat di-timbangkan untok n Pengerusi, berchakap dalam masaalah Kementerian Penerangan dan Penyiaran ini ada-lah memerlukan masa yang ini. Dan bagitu juga di-atas usaha2 Kementerian Penerangan dan Penyiaran ini memupok dan memberi kesedaran dalam erusi, saya mengalu2kan di-atas usaha Kementerian Penerangan dan Penyiaran ini yang telah menambah bilangan Pegawai2 lah memberi tahniah dan pujian kapada Kementerian Penerangan dan Penyiaran ini. Tuan Pengerusi, Ahli Yang Berhormat

Text: 17 February 1967

Yang Berhormat Menteri Penerangan dan Penyiaran yang mana memberi layanan bahasa Banjau untok di-siarkan di-Radio Malaysia Sabah dan dengan ini juga, Tuan Pengerusi, saya merayu dan berharap bahasa Banjau tersebut dapat di-siarkan sa-belum pilehan raya yang akan datang ini di-Sabah. [...]

Tuan Pengerusi, saya dapat tahu Jabatan Penerangan dan Penyiaran di-Sabah maseh banyak kekurangan kereta2 terutama sa-kali perahu2 atau pun jongkong. Kerana sebab ini-lah kerja2 mereka untok memenohi kehen-dak orang ramai tidak dapat di-penohi. Tuan Pengerusi, saya selalu mengikuti warta berita Radio Malaysia Barat dalam bahasa kebangsaan Malaysia atau pun bahasa Melayu menerusi Radio Malaysia Sabah sa-chara lang-song di-siarkan dari Malaysia Barat. Saya dapati sangat2-lah memuaskan. Dan dengan ini, Tuan Pengerusi, saya merayu kapada Yang Berhormat Menteri Penerangan dan Penyiaran supaya bahasa Kadazan dan Iban juga di-beri layanan yang demikian.

(Dear Minister of the Ministry of Information and Broadcasting, I would like to express my appreciation for broadcasting in Bajau language via Radio Malaysia Sabah and I would like to appeal to the Ministry to broadcast in that language before the upcoming election in Sabah [...] I know the Department of Information and Broadcasting in Sabah still lacks transportation; this affects their work. Dear Speaker, I have heard news by the Radio Channels from West Malaysia in the national language via Radio Malaysia Sabah, I found the news very satisfying. I hope the Ministry of Information and Broadcasting can treat Kadazan and Iban languages equally) In this session, the MP from Sabah expresses his concern regarding the treatment of native languages of Sabah that are used in Broadcasting. He hopes that more local languages can be used and treated equally. He initially expresses his hope that the information on the upcoming election can be done in Bajau language. In this session, the issue raised is related to the utility of broadcasting as a medium of information and nation building. 


\subsection{P5 Recruitment of The Arm Forces}

\section{Concordance:}

lui surat-surat khabar. (Z?) Melalui radio. (c) Penyiaran melalui Jabatan-jabatan Penerangan Negeri. (J) Penyiaran melalui Fokuis dan Scope dalam semua bahasa; (d) membuat penyiaran melalui Jabatan-jabatan Penerangan Negeri-negeri; (e) menyebarkan

Text: 16 JUN 1980

Beberapa langkah telah dan sedang diambil untuk menggalakkan warganegara Malaysia memasuki Angkatan Tentera:

(a) Iklan melalui surat-surat khabar.

(b) Melalui radio.

(c) Penyiaran melalui Jabatan-jabatan Penerangan Negeri.

(J) Penyiaran melalui pasukan-pasukan Angkatan Tentera.

(The army needs to encourage Malaysian citizens to join them. A few steps have been taken to solve the issue of recruitment faced by the army:

a) Advertising in newspaper.

b) Over the radio.

c) Broadcasting via the state's Department of Information.

d) Broadcasting via the army's teams.)

In this P5, the issue of the recruitment of the army is addressed with the mention of the use of broadcasting. In this context, the role or function of broadcasting is evoked. The collocation of penyiaran and penerangan takes place here to refer to the role of the Department of Information (Penerangan).

\subsection{P10 Broadcasting Rules and Policies}

\section{Concordance:}

\footnotetext{
sebanyak RM15.7 juta untuk penggantian peralatan penyiaran di Institut Penyiaran Tun Abdul Razak (IPTAR) dan dan Prestasi 2000, objektif program Perkhidmatan Penyiaran ialah menyediakan perkhidmatan penyiaran, menyebarkan maklumat melalui radio embantu memartabatkan peranan RTM sebagai jentera penyiaran kerajaan dan bukannya alat penyiaran amnya. Begitu juga

$\mathrm{n}$ dan radio itu diperuntukkan lebih banyak kepada penyiaran-penyiaran berhubung dengan agama. Ini adalah satu kesedaran atan maklumat dan juga penggunaan sistem on line, penyiaran-penyiaran dan juga yang berkait dengan telekomunikasi di i pengiklanan tetapi kita tidaklah boleh menyekat penyiaran-penyiaran iklan di stesen-stesen penyiaran komersial yang libus, yang diaturkan secara berkurikulum melalui penyiaran-penyiaran video tele-conference dan sebagainya ke seluruh ke atas memantapkan usaha-usaha bagi menggalakkan penyiaran-penyiaran yang bersifat patriotisme. Dan, bagi sat imana hendak menggunakan tapak bangunan itu untuk penyiaran yang boleh [Ketawa].. . penyiaran yang boleh dimanfaat sebanyak-
} 
Text: 4 April 2000

Sejak Kementerian Tenaga, Komunikasi dan Multimedia ditubuhkan, ada beberapa kekeliruan dan perpindahan berlaku. Kita dapati soal-soal yang berkaitan dengan dasar penyiaran negara kini kelam-kabut kerana selepas diletakkan di bawah kementerian baru, rangka dasar dan peraturan-peraturan penyiaran seolah-olah tidak lagi dikawal. Sehingga ini ketika kita memasuki alaf baru, kini belum disajikan dengan satu dasar komunikasi yang konkrit. Saya masih ingat Dasar Komunikasi Negara mula digubal ketika Menteri Penerangan diterajui oleh bekas Menteri Penerangan yang lalu, selepas beberapa menteri dan kini katanya dasar ini digubal oleh Kementerian Tenaga, Komunikasi dan Multimedia, ia belum menampakkan tanda positif.

(Since the Ministry of Energy, Communication and Multimedia was established, there have been several confusions and transfers that have taken place. We found that issues related to National Broadcasting Policy is in topsy-turvy since it is housed under the new ministry; Policy Planning and Regulations are seemed to have lost their control. Until now at the threshold of the new era, we still have not seen a concrete Communication Policy. I remember that the National Communication Policy was legislated when under the erstwhile Minister, and afterwards by other Ministers. Now it is said that it is being legislated by the Ministry of Energy, Communication and Multimedia, it has not shown any positive sign).

In P10, one MP commented on the issue of the lack of proper Policy for communication. The problem, as he pointed out, stems from the confusion arises in the naming and the constitution of the new Ministry. He takes the new ministry to task so that the National Communication Policy could be legislated accordingly.

\section{P13 Islamic Broadcasting Channel}

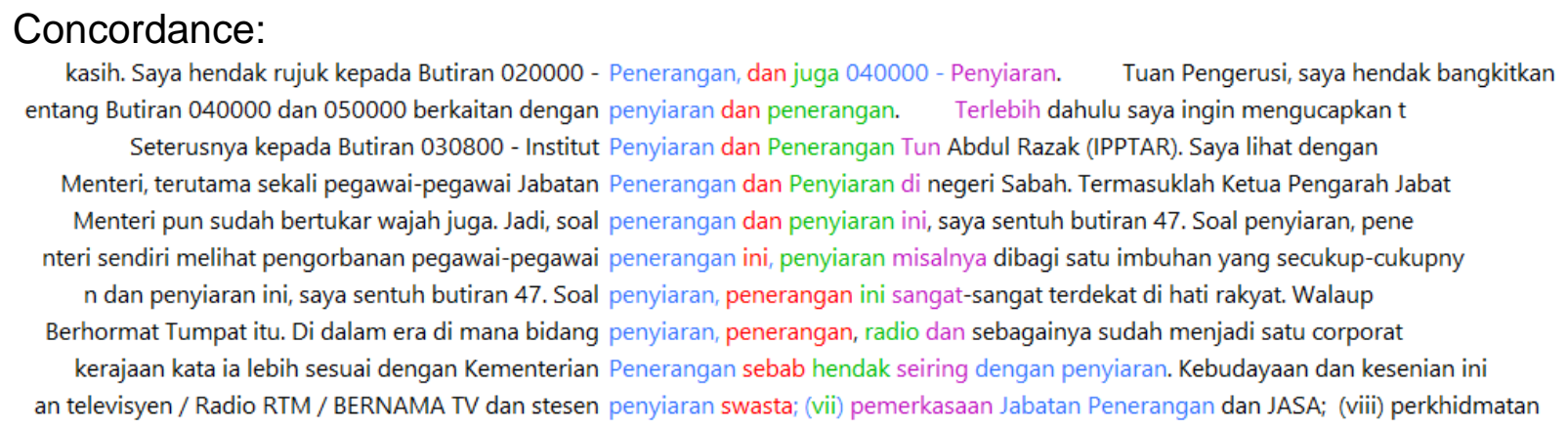


Text: 17 Julai 2013

$[\ldots]$

berapakah pulangan yang dapat daripada segi pengiklanan yang dibuat oleh TV AlHijrah? Oleh kerana TV AlHijrah hanya menerima sejumlah peruntukan yang terhad daripada kerajaan setiap tahun, maka sumber pendapatan dari iklan adalah perlu bagi menampung perbelanjaan operasinya.

[...] siapakah yang berada di dalam pengurusan TV AlHijrah? Apakah mereka terdiri daripada orang yang profesional dan mempunyai latar belakang dalam bidang media elektronik?

[...] apakah perbezaan konsep antara TV AlHijrah dengan TV yang ada sekarang? Bagaimana pendekatan TV AlHijrah?[...]

Bagaimana dengan sambutan daripada kalangan penonton? Apakah rating TV AlHijrah?

(What is the financial gain from advertising that TV Al Hijrah has obtained? Since AlHijrah receives limited government allocation each year, the income from advertising is necessary.

[...] Who are in the top management of TV AlHijrah? Are they professionals with electronic media background?

[...] What is the difference between AlHijrah as an Islamic channel with the existing TV channels. What is its approach?

What about the reception among its audience? What is its rating?)

In this $\mathrm{P} 13$, the issues related to the establishment and governance of AlHijrah were raised by one MP. AlHijrah as an Islamic TV channel is under scrutiny as it receives financial allocation from the government. Issues that are raised point to the need of check and balance in the context of media ownership and control.

In the case of broadcasting, it is found that broadcasting:

a) Reached the peak in P1

b) Has the lowest frequency in P5

c) The highest collocation with information in P2

d) The lowest collocation with information in P3

e) The first collocation of broadcasting with information (consistent collocation) begins in P1 until P3

f) Broadcasting has consistent collocate with information from P1 until P3 only and disappears along P4 until P13.

Based on the above finding, the textual analysis focuses on P1, P2, P3 and P5. 


\subsection{P1 Merger of Ministry of Broadcasting and Information}

\section{Concordance:}

Ministry is now responsible for the Department of Broadcasting and Information in the two States of Sabah

this House expects from the Assistant Minister of Broadcasting and Information is a service to be confined Information is a service to be confined to broadcasting and information on behalf, perhaps, of the Government

28\x97Information 7,256,163 (b) Head S. 66H\x97 Broadcasting and Information (Sabah)... 1,394,255 (c) Head S. $67 \mathrm{~K} \backslash \times 97$

are playing complementary roles. Head S. $66 \mathrm{H} \backslash x 97$ Broadcasting and Information (Sabah) Mr Chairman, Sir, with the this portfolio we have the twin departments of Broadcasting and Information Services which include the Malayan Film speak on the allocation to the Ministry of Broadcasting and Information under the Supply Bill. Sir, the

$\mathrm{n}$ Agong probably before the Assistant Minister of Broadcasting and Information was born. We were together in

Text: 7 December 1960

Head Ministry of Information and Broadcasting there will be a slight increase in the overall expenditure this year notably under P.E. This, it will be agreed, is to be expected as the Ministry is now expanding both in scope and activity. [...] I am now glad to say that within the short time, the Ministry had successfully initiated the planning and organisation of a new Department the Department of Television which is now its direct responsibility [...] it has been found necessary to create a number of professional posts which, in actual fact, integrate two common services of both Department of Radio and Department of Television. I refer in particular to the post of Chief Commercial Broadcasting Officer who is now the Ministry official. This officer will be responsible to the Ministry for the policy as well as the day-to-day running of commercial broadcast over radio and television. This is but a logical arrangement, in view of the fact that there must necessarily be one policy in commercial broadcasting both for radio and television.

In this session of $\mathrm{P} 1$, one MP rationalizes the importance of budget increase for the Ministry of Information and Broadcasting, considering the merger of the Ministry, by initiating a new Department of Television with the merge with the Department of Radio. This is seen as strategic as it will iron out the problem with having different policies on commercial broadcasting for both radio and television, despite the larger the scope of the Ministry.

\subsection{P2 Governance of Three Divisions of The Ministry Under One Roof}

\section{Concordance:}

30. Dr Tan Chee Khoon asks the Minister of Information and Broadcasting to state the cost of: (a)

31. Dr Tan Chee Khoon asks the Minister of Information and Broadcasting to state whether (a) the Film

32. Dr Tan Chee Khoon asks the Minister of Information and Broadcasting to state why Television Malaysia and

33. Dr Tan Chee Khoon asks the Minister of Information and Broadcasting to state why the three divisions

34. Dr Tan Chee Khoon asks the Minister of Information and Broadcasting to state whether it is true 
Dr Tan Chee Khoon asks the Minister of Information and Broadcasting to state why the three divisions of his Ministry, viz., Broadcasting, Film Unit, and Television are not housed under one roof; and whether such move would ensure savings and help in the economic deployment and interchange of staff.

[...] The Malayan Film Unit Centre at Petaling Jaya was planned several years before the need arose for the New Broadcasting Centre to be put up at Pantai Valley. Hence the Film Unit will be housed in separate premises. In fact, its diversification could well be an advantage especially in times of emergency for the sake of security, safety and other obvious reasons.

In this parliament session of P2, the MP asks about the reason why the divisions under the Ministry of Information and Broadcasting are not placed under one roof. The answer given reflects the social political situation of that time as the placing of those divisions is governed by security and safety need. This shows that the three divisions have disparate functions, which reflects their need to be located at different locations.

\subsection{P3 Unbias and Impartial Reporting of National News}

\section{Concordance:}

the terms of reference of the Director of Information and Broadcasting? Is there a term of reference?

National Union of Employees in the Ministry of Information and Broadcasting 725 KesaTuan Bidan2 Kerajaan Malaya 255 National see the same Peristiwa programmes of, say, the Information and Broadcasting Minister planting a tree and speechmaking an increase of $\$ 12$ million, while the Ministry of Information and Broadcasting needs $\$ 13$ million more. Ordinary Budget revenue is a national institution, I hope that our information and broadcasting service would be .... Menteri Muda Hal is a national institution I hope that our information and broadcasting service would be unbiased and impartial

Text: 11 March 1971

Mr Speaker, may I now touch briefly on broadcasting. Since Radio Malaysia is a national institution, I hope that our information and broadcasting service would be unbiased and impartial in its reporting of national news and national events. In this respect, may I ask what are the terms of reference of the Director of Information and Broadcasting? Is there a term of reference? There has been a time in the past when Radio Malaysia (Sarawak) was used as a political tool by the Alliance Party and I refer in particular to the period immediately after Dato' Ningkan, who was the then Chief Minister of Sarawak when he was unconstitutionally sacked by His Excellency the late Govemor of Sarawak. Because of the irresponsible broadcasting made by Radio Malaysia (Sarawak) at that time it has brought disrepute and injured the credibility and the reputation of Radio Malaysia (Sarawak). Therefore, at all cost I would ask the Minister of Information to make sure that matters of national news, of national interest, should be broadcast and published impartially and also make sure that Radio Malaysia (Sarawak) cheeks [sic] its news and gives only true and correct news items. 
In this session of $\mathrm{P3}$, the issue raised by the MP concerns the role of national broadcasting in Malaysia. The MP questions the framing of national news towards a certain party, distorting the nature of the objectivity of news. This issue is raised due to the fact that radio was the main source of information that reaches more audience then another form of mass media, that is, the newspaper. As it was in 1971, the rate of reading literacy of this country, particularly in East Malaysia, there is a need for the National Radio broadcaster to remain impartial.

\subsection{P5 Quality Programs and Broadcasting Training}

Concordance:

oleh syarikat TV di Amerika seperti CBS (Central Broadcasting System), National Broadcasting Company dan juga American Broadcasting

Text: 1 December 1980

Kira-kira 90\% TV kita mengimport filem-filem daripada luar negeri ini adalah daripada Amerika yang dikeluarkan oleh syarikat TV di Amerika seperti CBS (Central Broadcasting System), National Broadcasting Company dan juga American Broadcasting Company. [...]

Oleh itu untuk menjaga keadaan yang lebih baik, untuk memberi kesempurnaan kepada penyiaran ini, saya mencadangkan kepada Kementerian ini supaya menghantar pegawaipegawai kita untuk berlatih ke Amerika kerana sekarang ini kita dapati ramai pegawai-pegawai kita ini berlatih hanya di Asia sahaja. [...]

Jika kita bandingkan dengan syarikat-syarikat penyiaran di Amerika yang sentiasa menerima perubahan dan juga mencari cara-cara baru.

(About $90 \%$ of our TV programs imported films from abroad especially produced by American TV companies such as CBS (Central Broadcasting System), National Broadcasting Company and American Broadcasting Company.

Therefore, to ensure better quality of local broadcasting programs, I would like to suggest that the Ministry start sending their officials to the States as most of them are trained in Asia only, and not focusing on BBC alone.

If compared to American broadcasting companies, they are open to changes and always look for new ideas)

In this parliament session of P5, there are two interrelated issues were discussed. One, the issue of the large number of imported broadcasting programs especially from America. What is being discussed centres on the idea that locally produced programs cannot compete with these imported programs dues to their low quality. This transpires the Speaker to suggest that more officials to be sent to America instead of within the region for training so that their work quality could improve. 


\section{CONCLUSION}

It can be concluded that the study by using keywords in Culturomics can lead to a more information about a cultural phenomenon or change. In this case, it reveals that the relationship between the keywords penyiaran and broadcasting points at the trends of the occurrences of both words. The frequencies generated hinted at the utility of both words in a formal discourse like in Malaysian Hansard. One such cultural change is in the decrease of the use of the word broadcasting in Parliament while showing the increase of the use of its Bahasa Malaysia counterpart, penyiaran. Besides that, the consistent collocations of both keywords also point at the way broadcasting (Information) and penyiaran (penerangan/information) is used, that is, in relation to its main function, dissemination of information as claimed by scholars like Asiah Sarji (1982) and even Shazlin Amir Hamzah (2019). Due to that, the fundamental role of broadcasting that is to disseminate information is confirmed by this study, and it also shows that it is less frequently used by policymakers.

One interesting observation that can be made is that both keywords regained their momentum in P10 that is from the year 1999 to 2003. They indeed went downwards after that. The limitation of this study is that it sets the MI score at 6 for significance purposes. For that reason, other relatively statistically insignificant collocate cannot be retrieved. It will be interesting to see what the collocates may be, and how they may increase in frequency due to the decrease in the use of the terms penyiaran and broadcasting in lieu of digital platform such as streaming TV and multimedia technology. The impact of this study is that it forewarns broadcasting scholars and practitioners of the need to understand the shift in the conception of broadcasting and therefore approach it differently. New way of theorizing the convergence of broadcasting with digital technology should also affect the methods employed in researching it.

\section{ACKNOWLEDGEMENT}

This research is supported by research grant coded KRA-2018-05, Universiti Kebangsaan Malaysia.

\section{BIODATA}

Dr Jamaluddin Aziz is an Associate Professor in Critical Media Studies at the Centre for Research in Media and Communication, FSSK, UKM. His research centres on the media and culture, gender and digital humanities. Email: Jaywalk@ukm.edu.my 


\section{REFERENCES}

Asiah Sarji. (1982). The historical development of broadcasting in Malaysia (1930 -1957) and its social and political significance. Media Asia, 9(3), 150-160.

Dominick, J. R. (2011). The dynamics of mass communication: media in transition. New York: McGraw-Hill International Edition.

Flew, T. (2012). The creative industries: Culture and policy. London: Sage.

Hajar Abdul Rahim. (2005). Impak konotasi budaya terhadap leksis: Satu kajian semantik berasaskan korpus ke atas perkataan perempuan dan wanita. Jurnal Budaya, 5(1), 83111.

Hand, E. (2011). Word play. Nature, 474, 436-440.

Hesmondhalgh, D. (2013). The cultural industries (3rd ed.). London: Sage.

Imran Ho-Abdullah, Anis Nadiah Che Abdul Rahman, \& Azhar Jaludin. (2017). The Malaysian hansard corpus. Culturomics Workshop UKM, 27 April 2017 (Unpublished).

Jamaluddin Aziz. (2019). Exploring gender issues associated with wanita/woman and perempuan/woman in Malaysian Parliamentary debates: A culturomics approach. Gema Online: Journal of Language Studies, 19(4), 278-303.

Juliana Abdul Wahab. (2006). Communication technology and the television industry in Malaysia. ARC Asia Pacific Future Network International Conference: Media, Policies, Culture and Futures in the Asia Pacific Region (pp. 1-16, Unpublished).

Kim, D. (2011). New regulatory institution for the convergence of broadcasting and telecommunications: A Korean case. Government Information Quarterly, 28, 155-163.

Leonard, H. (1993). Asian broadcasting: The changing scene. Media Asia, 20(3), 123-126.

Meor Zailan Sulaiman. (1992). The emergence of commercial television in Malaysia and its performance during the early period of its existence. Jurnal Komunikasi: Malaysian Journal of Communication, 8, 103-115.

Michel, J.-B., Shen, Y. K., Aiden, A. P., Veres, A., Gray, M. K., Pickett, J. P., .... Aiden, E. L. (2011). Quantitative analysis of culture using millions of digitized books. Science, 331(6014), 176-182.

Norhafiza Musa. (2019). Kandungan Netflix perlu ditapis. Sinar Harian. Diperoleh dari https://www.sinarharian.com.my/article/57567/BERITA/Nasional/Kandungan-Netflixperlu-ditapis

Norsimah Mat Awal, Azhar Jaludin, Anis Nadiah Che Abdul Rahman, \& Imran Ho-Abdullah (2019). "Is Selangor in Deep Water?": A Corpus-driven account of air / water in the Malaysian Hansard Corpus (MHC). GEMA online: Journal of Language Studies, 19(2), 9912.

Shazlin Amir Hamzah. (2019). A Malaysian nation brand: The dissemination of it by Radio Malaya via the song Tanah Pusaka. Jurnal Komunikasi: Malaysian Journal of Communication, 35(1), 90-202.

Tahmasebi, N., Borin, L., Capannini, G., Dubhashi, D., Exner, P., Forsberg, M., ... Risse, T. (2015). Visions and open challenges for a knowledge-based culturomics. International Journal Digital Library, 15, 169-187. 
Tangguh Okta Wibowo. (2019). Understanding movie streaming websites in Indonesia as unlimited movie access in the digital era. Jurnal Komunikasi: Malaysian Journal of Communication, 35(2), 247-259.

Treimane, L. (2011). Analyzing parliamentary discourse: Systematic functional perspective. KALBOTYA, 63(3), 78-94.

Umi Khattab. (2006). 'Non' mediated Images: public culture and (state) television in Malaysia. The International Communication Gazette, 68(4), 347-361. 